\title{
ASCERTAINING THE MEANING OF LEGISLATION - A QUESTION OF CONTEXT
}

\author{
Cathy Nijman*
}

\begin{abstract}
It has been said that "no word in an Act can be safely interpreted out of its context". Yet, Parliament was sufficiently concerned about the courts' use of external context as an aid to statutory interpretation to decide consciously to omit reference to "context" when enacting section 5(1) of the Interpretation Act 1999. This paper investigates the reasons for Parliament's concern. It examines cases decided before and after the enactment of section 5(1) to establish past and present judicial practice when using external context as an interpretive aid. The paper concludes that the omission of "context from section 5(1) has not altered the courts' principled approach to matters of interpretation, and it demonstrates that consideration of external context is an essential corollary to the purposive approach to statutory interpretation mandated by Parliament for over 100 years.
\end{abstract}

\section{INTRODUCTION}

Statutory interpretation was at the heart of the case described by the late Lord Cooke of Thorndon ${ }^{1}$ "[as] perhaps as important for the future of our country as any that has come before a New Zealand Court". ${ }^{2}$ New Zealand has placed heavy reliance on statute law since the country was first settled as a British colony. ${ }^{3}$ That early preference for statute law, accompanied by close attention to statutory construction and scheme, permeates much of New Zealand's legal history and

* Submitted as part of the LLB(Hons) programme at Victoria University of Wellington.

1 Robin Brunskill Cooke, Baron Cooke of Thorndon, 9 May 1926-30 August 2006.

2 New Zealand Maori Council v Attorney-General [1987] 1 NZLR 641, 651 (CA) Cooke P [Lands Case].

3 Rt Hon Dame Sian Elias "Transition, Stability and the New Zealand Legal System" (F W Guest Memorial Lecture, Dunedin, 23 July 2003) 10. 
legal method. ${ }^{4}$ As early as 1851 the colonial government issued an Interpretation Ordinance which provided: 5

The language of every ordinance shall be construed according to its plain import, and where it is doubtful, according to the purpose thereof.

The direction to adopt a purposive approach has been repeated in every interpretation statute since 1888. ${ }^{6}$ Section 6(i) of the Acts Interpretation Act 1908 and section 5(j) of the Acts Interpretation Act 1924 (the 1924 Act) were identical in terms to section 5(7) of the 1888 Act, but it is the current provision, section 5(1) of the Interpretation Act 1999 (the 1999 Act), that is the focus of this paper.

It has been said that "no word in an Act can be safely interpreted out of its context". ${ }^{7}$ As this paper demonstrates, a casual reading of any academic writing on statutory interpretation or of judgments grappling with issues of interpretation would appear to confirm this statement, with references to context abounding. Further, the Law Commission emphasises its importance as its 1990 report on a new Interpretation Act demonstrates. ${ }^{8}$ Given this apparent theoretical and practical consensus about the relevance of context in informing the interpretation of statutes, why did the government decline to include a reference to context when enacting section 5(1) of the 1999 Act? The government's decision raises a number of questions. For example, was there an intention to limit the courts' ability to look beyond the bare words of a statute (or the statute book as a whole) in ascribing meaning to Parliament's words? If so, has or should have, the omission of "context" in section 5(1) affected the courts' approach to the interpretation of legislation? Those questions require consideration of what (if any) contextual elements are relevant to issues of statutory interpretation and why. And could it be argued that if judges are (continuing) to have regard to context when interpreting statutes, they are acting contrary to Parliament's intention? As this paper will demonstrate, the answers to these questions are themselves dependent on the context in which they arise.

4 Rt Hon Dame Sian Elias "Sailing in a New Direction: The Laws of England in New Zealand" (UK-NZ LINK Foundation Speech, London, 12 November 2002) 12.

5 Rt Hon Sir Kenneth Keith "The Unity of the Common Law and the Ending of Appeals to the Privy Council" (2005) 54 ICLQ 197, 200.

6 George Tanner QC and Ross Carter "The Old Girl Still Looks Good to Me: Purposive Interpretation of New Zealand Legislation" (4 ${ }^{\text {th }}$ Australasian Drafting Conference, Sydney, 3-5 August 2005) 2.

7 J F Burrows Statute Law in New Zealand (3 ed, LexisNexis, Wellington, 2003) 119 [Statute Law in New Zealand].

8 New Zealand Law Commission A New Interpretation Act to Avoid "Prolixity and Tautology" (NZLC R17, Wellington, 1990) AJHR 1990 E 31L [NZLC R17]. See, for example, paras 44-48, 54, 64, 68, 71-72 and 100-103. 
The thesis to be explored in this paper is twofold. First, the omission of "context" in section 5(1) of the 1999 Act has made little or no difference to the way judges go about ascertaining the (disputed) meaning of legislation. Second, consideration of context is integral to the process of purposive statutory interpretation mandated by Parliament when section 5(1) was enacted.

The paper begins by examining the history of section 5(1) of the 1999 Act before moving to discuss general principles of statutory interpretation and how such principles are affected by the New Zealand legislative context, including the current and previous Interpretation Acts, and current and past approaches to legislative drafting.

This discussion is followed by an analysis of why matters of external context ${ }^{9}$ are an essential corollary to the statutory direction that courts adopt a purposive approach to the interpretation of legislation. The discussion is illustrated by a number of key contextual elements supported by an analysis of relevant New Zealand precedents. The paper concludes with an analysis of reported Court of Appeal and Supreme Court decisions from 2006, building on a previous reported study of the Court of Appeal's use of various resources as aids to statutory interpretation. ${ }^{10}$

\section{SECTION 5(1) OF THE INTERPRETATION ACT 1999 - A LEGISLATIVE HISTORY}

\section{A Law Commission}

The 1999 Act was passed in response to a 1990 Law Commission report, ${ }^{11}$ which, in its draft of a new Interpretation Act, recommended replacing the 85 words in section 5(j) ${ }^{12}$ of the 1924 Act with the following provision: ${ }^{13}$

9 The discussion focuses on external context because internal context is expressly referred to in the Interpretation Act 1999, ss 5(2) and (3).

10 James Allan "Statutory Interpretation and the Courts" (1999) 18 NZULR 439.

11 NZLC R17, above n 8.

12 Acts Interpretation Act 1924, s 5 reads:

\section{General rules of construction}

(j) Every Act, and every provision or enactment thereof, shall be deemed remedial, whether its immediate purport is to direct the doing of anything Parliament deems to be for the public good, or to prevent or punish the doing of anything it deems contrary to the public good, and shall accordingly receive such fair, large, and liberal construction and interpretation as will best ensure the attainment of the object of the Act and of such provision or enactment according to its true intent, meaning, and spirit.

13 This wording drew on art 31.1 of the Vienna Convention on the Law of Treaties (23 May 1969) 1155 UNTS 331: "A treaty shall be interpreted in good faith in accordance with the ordinary meaning to be given to the terms of the treaty in their context and in the light of its object and purpose." See NZLC R17, above n 8, 


\section{Ascertaining meaning of legislation-}

(1) The meaning of an enactment is to be ascertained from its text in the light of its purpose and in light of its context.

In the Law Commission's view "context", in terms of the language used and the wider societal and political context, was "inevitably part of the process of finding meaning". 14 "Context" was not defined, but the Commission noted that in addition to internal context and the social and political context in existence at the time an enactment is being interpreted, context could encompass specific non-statutory law, for example the mental and factual aspects of criminal liability, ${ }^{15}$ principles of judicial review, ${ }^{16}$ or New Zealand's "extensive network of treaty obligations". ${ }^{17}$ Each of the examples given was supported by official reporter series citations, indicating that the courts were already using external context to inform their reading of statutes.

\section{B Parliament}

The Commission's "persuasive arguments" 18 on the relevance of context notwithstanding, the Bill's explanatory note indicated the words "in light of its context" had been omitted because "the term ... is imprecise" and "suggests a meaning that might well go beyond the approach of the Courts currently in interpreting legislation". ${ }^{19}$ This appears to be a veiled reference to what was then (and is still) pejoratively referred to as judicial activism.

Judicial activism is a term used in a negative, populist sense by those who disapprove of a particular judgment, or who see judges as crusaders for a cause. ${ }^{20}$ For the purposes of this paper, judicial activism means a judge (1) does not apply all and only such relevant, existing, clear,

para 38; see also Rt Hon Sir Kenneth Keith "The Impact of International Law on New Zealand Law" (1997) 5 Waikato LR 1.

14 NZLC R17, above n 8, para 71.

15 Ibid, para 45.

16 Ibid, para 71

17 Ibid, para 72.

18 New Zealand Law Society "Submission on the Interpretation Bill" (3 April 1998) para 21.

19 Interpretation Bill 1998 no 90-2, iii.

20 Rt Hon Dame Sian Elias "'The Next Revisit': Judicial Independence 7 Years On" $\left(8^{\text {th }}\right.$ Neil Williamson Memorial Lecture, Christchurch, 30 July 2004) 13. See also Hon Justice Dyson Heydon "Judicial Activism and the Rule of Law" (2004) 10 Otago LR 493, 495; Roger Kerr "Appeals to the Privy Council" (New Zealand Bar Association Conference, Queenstown, 22 July 1995) www.nzbr.org.nz (accessed 5 July 2006); and, in response, Lord Cooke of Thorndon "Foreword" in Peter Spiller New Zealand Court of Appeal 19581996: A History (Thomson Brookers, Wellington, 2002) x. 
positive law as is available, and (2) whose judgments reflect her or his moral, political or religious views as to what the content of the law should be. ${ }^{21}$

The Minister of Justice said "context" had been omitted from clause 5(1) because "[i]t would be unwise to sanction a form of words that might encourage some courts to depart from the primary objective of discerning parliament's intention in enacting the relevant statute." 22 The select committee rejected the New Zealand Law Society's submission recommending that "context" be reinstated, noting in its commentary that "[a] direction to take 'context' into account may lead to a more liberal approach to statutory interpretation that departs from the words of the statute and therefore the purpose of Parliament." 23 The omission of "context" was not challenged during the debates on the Bill, ${ }^{24}$ so section 5(1) of the 1999 Act was enacted as follows:

\section{Ascertaining meaning of legislation-}

(1) The meaning of an enactment is to be ascertained from its text in the light of its purpose.

While there was no overt criticism of the judiciary during the debates on the Bill, ${ }^{25}$ it is submitted that the concern implicit in the decision to omit the reference to context can be attributed to a fundamental misunderstanding of the motivation of judges who, in a number of high-profile cases over the preceding decade, ${ }^{26}$ had been following Parliament's directive to adopt a purposive approach to statutory interpretation.

21 Tom Campbell "Judicial Activism - Justice or Treason?" (2003) 10 Otago LR 307, 312 [Judicial Activism Justice or Treason?"]

22 Hon D A M Graham (2 December 1997) 565 NZPD 5910.

23 Interpretation Bill 1998, no 90-2, iii.

24 See, for example, the Consideration of the Report of the Justice and Law Reform Committee (15 June 1999) 578 NZPD 17342-17350 and the debate in the Committee of the Whole House (29 July 1999) 579 NZPD 18686-18693.

25 This reticence can be contrasted with recent debates on the Foreshore and Seabed Bill, the Supreme Court Bill, and the speech of the Hon Dr Michael Cullen on the occasion of the $150^{\text {th }}$ anniversary of Parliament (24 May 2004) 617 NZPD 13191-13193.

26 Lands Case, above n 2. See also New Zealand Maori Council v Attorney-General [1989] 2 NZLR 142 (CA) [Forest Assets]; Tainui Trust Board v Attorney-General [1989] 2 NZLR 513 (CA) [Coal Case]; Simpson v Attorney-General [1994] 3 NZLR 667 (CA) [Baigent's Case]. 


\section{STATUTORY INTERPRETATION - PRINCIPLES AND PURPOSE}

\section{A General Principles of Interpretation}

The generic common law rules of statutory interpretation are well documented elsewhere. ${ }^{27} \mathrm{~A}$ brief summary will suffice for current purposes. There are three primary "rules" of statutory interpretation. The "literal rule" sees words given their ordinary meaning regardless of the consequences of that interpretation; ${ }^{28}$ the "golden rule" enables words to be given a non-literal meaning if that avoids a contradictory or absurd outcome; ${ }^{29}$ and the "mischief rule," famously articulated in Heydon's Case, ${ }^{30}$ says that where possible, words should be construed in a way that "suppresses the mischief and advances the remedy" the legislation is aimed at. ${ }^{31}$ Not all statutes are passed to "cure a mischief" - they may aim to foster a positive social purpose - but the style of interpretation the "mischief rule" advocates is closely aligned to the purposive approach ${ }^{32}$ discussed in Part $\mathrm{C}$ below. In New Zealand these general, judge-made rules of interpretation have long been supplemented (and, it has been suggested, supplanted) ${ }^{33}$ by legislation.

\section{B Statutory Interpretation - The New Zealand Legislative Context}

The words Parliament uses to express its intention remain the starting point for all statutory interpretation, ${ }^{34}$ and where their meaning is plain they are also the end point. ${ }^{35}$ However, while judges are confined by the words of a statute, they are not confined to them. ${ }^{36}$ The long-standing statutory directive for purposive interpretation makes that clear. ${ }^{37}$

27 See, for example, Francis Bennion Understanding Common Law Legislation - Drafting and Interpretation (4 ed, Oxford University Press, Oxford, 2001) [Understanding Common Law Legislation]; and Burrows Statute Law in New Zealand, above $\mathrm{n} 7$.

Michael Zander The Law-Making Process (6 ed, Cambridge University Press, Cambridge, 2004) 130.

29 Burrows Statute Law in New Zealand, above n 7, 114.

30 Heydon's Case (1584) 3 Co Rep 7a, 7b; 76 ER 637, 638.

31 Bennion Understanding Common Law Legislation, above n 27, 133.

32 Burrows Statute Law in New Zealand, above n 7, 133.

$R$ v Pora [2001] 2 NZLR 37, paras 102-103 (CA) Keith, Gault and McGrath JJ.

Auckland City Council v Glucina [1997] 2 NZLR 1, 4 (CA) Blanchard J for the Court.

5 Waitakere City Council v Khouri [1999] 1 NZLR 415, 421 (CA) Tipping J for the Court.

36 Rt Hon Sir Kenneth Keith "Sovereignty at the Beginning of the $21^{\text {st }}$ Century: Fundamental or Outmoded? (Sir David Williams Lecture, Cambridge, 7 November 2003) 19 ["Sovereignty at the Beginning of the $21^{\text {st }}$ Century"].

$37 R$ v Pora, above n 33, para 104 Keith, Gault and McGrath JJ. 
1 Section 5(j) of the 1924 Act-a fair, large, and liberal approach to the interpretation of legislation

The "fair, large, and liberal" part of section 5(j) was often quoted by those asking for (or giving) a statute an expansive interpretation, ${ }^{38}$ but a purposive interpretation may also be a narrow or restrictive one, for example where fundamental rights are engaged. ${ }^{39} R$ v Jefferies $^{40}$ involved a challenge to the admissibility of evidence. A breach of section 21 of the New Zealand Bill of Rights Act 1990 (BORA) was alleged. The issue on appeal was whether the police had lawful authority to conduct a warrantless search when there was "reasonable suspicion" to believe the defendant's vehicle was fleeing the scene of a serious crime. As Cooke P noted: ${ }^{41}$

In considering the general provisions of the Police Act [s 37] as a potential source of authority much turns on the approach to statutory interpretation. The fair, large and liberal approach enjoined by the legislature for every Act, by s 5(j) of the Acts Interpretation Act 1924, is never to be lost sight of. The Courts have tended, however, to see that injunction as consistent with a somewhat jealous scrutiny of Acts which may encroach on highly valued traditional liberties.

Section 5(j) required judges to avoid an excessively literal approach to interpretation which, with its "myopic attention" to the words used, often had the effect of frustrating Parliament's intention, ${ }^{42}$ sometimes deliberately so. ${ }^{43}$ It was a "statutory endorsement of the best judicial practice". ${ }^{44}$ However, as late as 1963 judges were criticised for ignoring this statutory directive. ${ }^{45}$ The purposive approach has become pre-eminent only in the last 40 years, and the last 25 years in particular. $^{46}$ In the writer's opinion, that change can be traced directly to the establishment of a separate Court of Appeal in 1957. ${ }^{47}$ Until then, appeal judges were seconded from the Supreme

38 Mollgaard v Accident Rehabilitation and Compensation Insurance Corporation [1999] 3 NZLR 735, paras 25-26 (CA) Hammond J for the Court; See also $R v K a h u$ [1995] 2 NZLR 3, 5-6 (CA) Cooke P, Richardson, Casey and Hardie Boys JJ (McKay J dissenting).

39 Burrows Statute Law in New Zealand, above n 7, 136.

$40 \quad R$ vefferies [1994] 1 NZLR 290 (CA).

41 Ibid, 296 Cooke P (emphasis added).

42 J F Burrows "The Changing Approach to the Interpretation of Statutes" in David Carter and Matthew S R Palmer (eds) Roles and Perspectives in the Law: Essays in Honour of Sir Ivor Richardson (Victoria University Press, Wellington, 2002) 981, 983 ["The Changing Approach to the Interpretation of Statutes"].

43 J Willis "Statute Interpretation in a Nutshell" (1938) 16 Can Bar Rev 1, 17.

44 Rt Hon Sir Ian McKay "Interpreting Statutes - A Judge's View" (2000) 9 Otago LR 743, 751.

45 D A S Ward "A Criticism of the Interpretation of Statutes in New Zealand Courts" [1963] NZLJ 293.

46 Hon John McGrath "Purpose, Hansard, Rights, and Language" in Rick Bigwood (ed) The Statute - Making and Meaning (LexisNexis, Wellington, 2004) 227, 229 ["Purpose, Hansard, Rights and Language"].

47 Judicature Amendment Act 1957. 
Court. ${ }^{48}$ The judges lacked the time and resources that would have enabled them to develop a distinctive body of New Zealand law. ${ }^{49}$ In cases involving statutory interpretation, "slavish adherence" to English precedents ${ }^{50}$ was supplemented by reliance on "statements of principle in English textbooks ... and classical judicial statements developed in England over the centuries" meaning that statutes were not analysed in line with section $5(\mathrm{j}) .{ }^{51}$ The dependence on English authorities meant literalism was the dominant style of interpretation. Extrinsic material was rarely referred to. ${ }^{52}$

The permanent Court of Appeal, however, demonstrated a willingness to depart from English precedents and to develop New Zealand law in a way suited to domestic needs. ${ }^{53}$ That trend received added impetus in the 1980s and 1990s with an increase in the number of "controversial, public-law type cases", such as those involving the Treaty of Waitangi and Bill of Rights issues. ${ }^{54}$ Many of those cases involved ambiguous legislation that obliged the courts to "fill in the gaps" necessitating consideration of the context in which the legislation was enacted and the context in which it was being applied. ${ }^{55}$ While the Court of Appeal was simply following Parliament's directive requiring it to adopt a purposive approach to statutory interpretation, it is not difficult to see how disquiet over the outcome of cases such as the Lands Case $^{56}$ and Baigent's Case ${ }^{57}$ may have influenced the decision to omit the reference to "context" from section 5(1). However, it would be a mistake to infer from that apparent concern about outcomes an intention to restrict the process by which the courts ascertain meaning.

2 Section 5(1) of the 1999 Act

(a) Something old or something new?

48 Renamed the High Court in 1980: Judicature Act 1908, s 3.

49 Peter Spiller, Jeremy Finn and Richard Boast A New Zealand Legal History (Brookers, Wellington, 2001) 227.

50 Rt Hon Dame Sian Elias "Something Old, Something New: Constitutional Stirrings and the Supreme Court" (Robin Cooke Lecture 2003, Victoria University of Wellington, 11 December 2003) 6.

51 Hon John McGrath "Reading Legislation and Ivor Richardson" in Carter and Palmer (eds), above n 42, $1017,1021$.

52 Burrows "The Changing Approach to the Interpretation of Statutes", above n 42, 981.

53 Spiller, Finn and Boast, above n 49, 240.

54 Ibid, 239-240.

55 Lands Case, above n 2; see also Forest Assets, above n 25; Baigent's Case, above n 25.

56 Lands Case, ibid.

57 Baigent's Case, above n 26. 
The Bill's explanatory note and the select committee report ${ }^{58}$ both affirm that clause 5 was intended to "[confirm] the purposive approach to the interpretation of legislation inherent in section 5(j) and adopted by the Courts ...". The change to the "plain English" style of drafting in the 1999 Act did lead to some argument that the newer, shorter section meant something different from the old, ${ }^{59}$ but the academic consensus is that the effect of sections $5(\mathrm{j})$ and $5(1)$ is the same. ${ }^{60}$ Both focus on interpreting words, not creating new ones. ${ }^{61}$ Further, the courts have ruled that Parliament did not intend any substantive change to the "fair, large and liberal" approach required by section $5(\mathrm{j})$ despite the change in language. ${ }^{62}$

(b) A question of purpose

Section 5(1) itself gives rise to an important question of statutory interpretation. What "purpose" is to be considered in ascertaining the meaning of an enactment? And what if an Act has more than one identifiable purpose? Is the relevant "purpose" or "purposes" limited to the purpose provision of the enactment (if it has one) or, for an older Act, its long title? Or is it something other than the purpose(s) as enacted, that is, the "social, economic or other end that Parliament was hoping to achieve by the Act"? ${ }^{63}$ It is submitted that the former is necessarily shaped by the latter. Parliament does not legislate in a vacuum. The "social, economic or other end" forms part of the context in which legislation must be interpreted if the interpretation is to be fully informed. Nevertheless, it would be wrong to suggest that section 5(1) gives judges interpreting legislation carte blanche. Purposive interpretation has its own inherent limits.

\section{Purposive Interpretation}

The purposive approach mandated by section 5(1) is tied to text so it cannot be used to change the plain meaning of words used. A judge cannot use the purposive approach to justify rewriting a statute as she or he would have written it, ${ }^{64}$ nor does it justify attributing a meaning to words

58 Justice and Law Reform Committee "Report on the Interpretation Bill" [1996-99] LXV AJHR I 597.

59 Burrows Statute Law in New Zealand, above n 7, 84.

60 Ibid, 136; Kate Tokeley "Trends in Statutory Interpretation and the Judicial Process" in Carter and Palmer (eds), above n 42, 965, 969; Palmer "Using Constitutional Realism to Identify the Complete Constitution: Lessons from an Unwritten Constitution" (2006) 54 Am J Comp L 1, 582, 612.

61 Tokeley, ibid, 969.

62 See Jack $v$ Manukau City Council (14 December 1999) HC AK M 1698/99, para 15 Randerson J; $R v$ Rongonui [2000] 2 NZLR 385, para 161 (CA) Thomas J; $R$ v Pora, above n 33, para 103 Keith, Gault and McGrath JJ.

63 Burrows Statute Law in New Zealand, above n 7, 147 (emphasis in the original).

64 Hon Susan Glazebrook "Filling the Gaps" in Bigwood The Statute - Making and Meaning, above n 46, 153, 165 ["Filling the Gaps"]. 
arrived at by working backward from an assumed purpose, ${ }^{65}$ nor, it is submitted, a meaning arrived at by working backward from a perceived desirable result.

The increased use of extrinsic material in order better to understand a statute is concomitant with the modern purposive approach to interpretation. ${ }^{66}$ Previously limited to cases where a literal interpretation gave rise to an ambiguity, relevant contextual material is now regularly referred to when deciding upon the best solution from a range of competing meanings that a statute can reasonably bear. ${ }^{67}$ A judge's task is interpretation, not interpolation. ${ }^{68}$

The purposive approach requires words to be considered in their total context. ${ }^{69}$ It allows judges to disregard words inserted through error or inadvertence; ${ }^{70}$ likewise, judges may "supply" words omitted in error if the context makes it clear they were intended, ${ }^{71}$ or, for example, where a court faces a real and unanticipated problem and additional words are needed to "make the Act work" as Parliament intended. ${ }^{72}$ As the Hon Susan Glazebrook notes, when a judge engages in a "gapfilling" exercise in order to decide the case before her or him, "it must be assumed that Parliament wishes them to do so". ${ }^{73}$ Such "gap-filling," appropriately informed by context, is cognitive not creative. It is unfair to characterise it as judicial activism. By way of contrast, it has been suggested that literalism in interpretation actually allows judges greater scope to "impose their own preferred meaning on a statute" where Parliament has failed to use sufficiently express language to convey its intention. ${ }^{74}$

65 McKay, above n 44, 749.

66 Burrows "The Changing Approach to the Interpretation of Statutes", above n 42, 985.

67 Union Motor Ltd v Motor Spirits Licensing Authority [1964] NZLR 146, 150 (HC) Wilson J; see also Commissioner of Inland Revenue v Auckland Harbour Board [2001] 3 NZLR 289, 299 (PC) Hoffmann for the Court.

68 Rt Hon Lord Johan Steyn "The Intractable Problem of the Interpretation of Legal Texts" (2003) 25 Sydney LR 5, 7 .

69 McKay, above n 44, 747.

$70 \quad R v$ Panine [2003] 2 NZLR 63 (CA).

71 McKay, above n 44, 747.

72 Northland Milk Vendors Association Inc v Northern Milk Ltd [1988] 1 NZLR 530, 537-538 (CA) Cooke P for the Court. See also Commerce Commission v Fletcher Challenge Ltd [1989] 2 NZLR 554, 621 (HC) McGechan J and $R$ v Salmond [1992] 3 NZLR 8, 13 (CA) Cooke P; but see Proceedings Commissioner v A [1999] 1 NZLR 188, 198 (HC) Potter J.

73 Glazebrook "Filling the Gaps", above n 65, 155.

74 Jeffrey Goldsworthy "Parliamentary Sovereignty and Statutory Interpretation" in The Statute - Making and Meaning, above n 46, 187, 189. 
It is submitted that there can be no doubt that the purposive approach to interpretation mandated by section 5(1) (and its predecessor, section 5(j)) obliges the courts to consider external context where appropriate. The sharply contrasting judgments of the Court of Appeal and the Privy Council in Lesa $v$ Attorney-General ${ }^{75}$ demonstrate why this must be so. This case also demonstrates how a literal approach to statutory interpretation can subvert Parliament's intention. In delivering the opinion of their Lordships, Lord Diplock went "straight to the 1928 Act [to] consider its construction independently of the 1923 Act which it repealed". ${ }^{76}$ Because "their Lordships [were] unable ... to discern any ambiguity or lack of clarity in that language", ${ }^{77}$ that is where their interpretation rested. In contrast, the Court of Appeal adopted a purposive approach, considering the broader context of the 1928 Act, ${ }^{78}$ including the legislative history and the "international (United Nations), imperial and national" background to the relationship between New Zealand and Western Samoa. ${ }^{79}$ Sir Kenneth Keith has noted that: "the more comprehensive contextual approach of the New Zealand judges might be thought more appropriate where constitutional and international elements are central". ${ }^{80}$ The New Zealand and Western Samoan governments clearly thought so too: less than a month after the Privy Council delivered its opinion, an agreement substantially negating its effect had been negotiated. ${ }^{81}$

More recently, in Frucor Beverages Ltd $v$ Rio Beverages Ltd, ${ }^{82}$ the Court of Appeal had to decide whether to give section 34 of the Evidence Amendment Act (No 2) 1980 its literal meaning or whether section 5(1) justified departing from that meaning. The majority considered that a literal interpretation would render section 34 meaningless. ${ }^{83}$ In determining that a purposive interpretation was needed to give effect to Parliament's intention to confer a statutory privilege on patent attorneys and their clients, the majority looked at the complete legislative history, including the original Law Reform Committee recommendation, the select committee report, the Bill's explanatory note, and the Minister of Justice's speeches in the House. ${ }^{84}$ The reliance that patent attorneys and their clients had placed on the "accepted meaning" in the 20 years since enactment was a significant factor

\footnotetext{
75 Lesa v Attorney-General [1982] 1 NZLR 165 (PC).

76 Ibid, 169 Lord Diplock for the Court.

77 Lesa v Attorney-General, above n 76, 176-177 Lord Diplock for the Court.

78 British Nationality and Status of Aliens (in New Zealand) Act 1928, s 7.

79 Keith "Sovereignty at the Beginning of the $21^{\text {st }}$ Century", above $n$ 36, 19

80 Ibid, 20 (emphasis added).

81 Protocol of 21 August 1982 AJHR A.56; Citizenship (Western Samoa) Act 1982.

82 Frucor Beverages Ltd v Rio Beverages Ltd [2001] 2 NZLR 604 (CA).

83 Ibid, para 21 Thomas and Blanchard JJ (McGrath J dissenting).

84 Ibid, paras 13-21 Thomas and Blanchard JJ (McGrath J dissenting).
} 
justifying a purposive approach. ${ }^{85}$ This latter consideration reflects a point made elsewhere, namely that the true purpose of statutory interpretation is to find the contextual meaning of the text, or "what the words would convey to the reasonable person circumstanced as the parties were". ${ }^{86}$

The government's actions subsequent to the Privy Council decision in Lesa leave no room for doubt that it approved of the Court of Appeal decision and, it must be assumed, its use of context to inform interpretation of the statute. This reinforces the earlier conclusion that the concerns leading to the omission of "context" from section 5(1) derived from the unexpected outcome of certain highprofile cases, rather than the process followed and the consideration of context per se. And the absence of a legislative response to Frucor indicates that Parliament did not disapprove of the Court of Appeal's contextual analysis - or the outcome of that analysis.

Another recent Court of Appeal decision, Agnew v Pardington, ${ }^{87}$ confirms that the courts do not see the omission of "context" from section 5(1) as precluding consideration of external context where necessary. The question on appeal was whether section 30A of the Receiverships Act 1993 eliminated security holder interests in surplus funds when a receiver sold property ("interpretation $\mathrm{A}$ ) or whether its effect was limited to giving purchasers clear title ("interpretation $\mathrm{B} ") .{ }^{88}$ Glazebrook J noted that interpretation A was a "possible meaning", but went on to say: ${ }^{89}$

Even if $\mathrm{s} 30 \mathrm{~A}$ is viewed in isolation we favour interpretation $\mathrm{B} \ldots$.

The words of the section are not, however, to be viewed in isolation. Section 5(1) of the Interpretation Act 1999 provides that the meaning of an enactment must be ascertained from its text and in the light of its purpose. While the reference to context in the original Law Commission draft Interpretation Act was not enacted, there is no doubt that the text of a provision must be interpreted having regard to the Act as a whole and the legal system generally. The process of interpretation is an evaluative one.

The evaluative process undertaken in Agnew included consideration of the Personal Properties Securities Act 1999 ("Section 30A [and PPSA amendments] originated from the same Bill ... s 30A cannot be understood except in the context of the PPSA"), ${ }^{90}$ the select committee report, ${ }^{91}$ and equivalent provisions in other Acts. ${ }^{92}$ In concluding that interpretation B was consistent with the

85 Ibid, para 18 Thomas and Blanchard JJ (McGrath J dissenting).

86 Steyn, above n 68, 6.

87 Agnew v Pardington [2006] 2 NZLR 520.

88 Ibid, para 29 Glazebrook J for the Court.

89 Ibid, paras 29-31 Glazebrook J for the Court.

90 Ibid, para 17 Glazebrook $\mathrm{J}$ for the Court.

91 Ibid, para 24 Glazebrook $\mathrm{J}$ for the Court.

92 Ibid, para 41 Glazebrook $\mathrm{J}$ for the Court. 
words, purpose and context of section 30A, Glazebrook $\mathrm{J}$ noted that this interpretation was also "consistent with long-established principles in this branch of the law and it avoids absurd and unreasonable consequences ...".93 Her Honour acknowledged that interpretation B involved "reading down" section $30 \mathrm{~A},{ }^{94}$ confirming that a purposive interpretation may sometimes be a narrow one. For the sake of completeness, it is worth noting that before the Court's judgment was delivered, legislation clarifying section 30A (in line with interpretation B) was enacted. Although the Court declined to admit this later legislation in evidence, ${ }^{95}$ it does confirm that the Court's interpretation gave effect to the purpose for which section 30A was enacted. Lesa, Frucor and Agnew reinforce the importance of external context as an objective aid to interpretation when meaning is disputed.

\section{CONTEXT: A PART OF THE WHOLE}

Having established that the purposive approach to statutory interpretation mandated by section 5 (1) requires consideration of external context, this section of the paper elaborates on why and when it may be necessary for the courts to have regard to extrinsic material when interpreting legislation. Successive governments have accepted that compliance with legal principles and obligations including the Privacy Act 1993, the Human Rights Act 1993, BORA, New Zealand's international obligations, and the principles of the Treaty of Waitangi are mandatory relevant considerations when legislation is drafted. ${ }^{96}$ If these issues must be considered by those who make New Zealand's laws, it is only logical they be considered, where necessary, by the judges responsible for ascertaining the legal meaning of those laws, especially when some time has passed since enactment, or when a statute is expressed in general terms. Support for this conclusion is found in the following analysis of two of these considerations: BORA and the Treaty of Waitangi. Other aspects of external context that judges use to inform interpretation - legislative history, time and precedent - are discussed and further support this conclusion.

\section{A Legislative History}

The select committee considering the Bill which became the 1999 Act rejected a submission recommending the inclusion of a legislative history at the end of every printed statute because "if included, [it] may be used as an aid to interpretation, which could lead to uncertainty in the interpretation of legislation". 97 However, a legislative history has been included in all new Acts

93 Ibid, para 42 Glazebrook J for the Court.

94 Ibid, para 43 Glazebrook J for the Court.

95 Ibid, para 28 Glazebrook J for the Court.

96 Cabinet Office Cabinet Manual 2001 (Cabinet Office, DPMC, Wellington, 2001) para 5.35; Legislation Advisory Committee LAC Guidelines (September 2003) chs 4, 5 and 6.

97 Interpretation Bill 1998, iii. 
and reprints since 1 January 2000. ${ }^{98}$ In the writer's view the committee's comment supports the inference that concerns about judicial activism prompted the omission of "context" from section 5(1); and, further, that Parliament wanted to send a signal that when interpreting a statute, judges should confine themselves to the words of that statute. The comment indicates a fundamental misunderstanding of basic tenets of statutory interpretation, particularly the informed interpretation rule $^{99}$ and its close relationship with purposive interpretation. As the doyen of statutory interpretation, Francis Bennion, notes, the courts have always had "the power, indeed the duty to consider ... the legislative history". 100

The context that the legislative history provides is useful in identifying the "social, economic, or legal mischiefs" that Parliament intended to address. ${ }^{101}$ Legislative history in terms of earlier statutes dealing with the same subject matter is also relevant. Inferences as to parliamentary intention and meaning can be drawn either from the re-enactment of a provision in substantially the same terms or, conversely, from changes in wording. ${ }^{102}$ However, legislative history cannot be used as a direct source of meaning, nor can it be used as evidence of Parliament's subjective intention in order to remedy drafting defects. ${ }^{103}$

The exclusionary rule which precluded reference to Hansard was an acknowledged exception to the informed interpretation rule, ${ }^{104}$ but was never as clearly established in New Zealand as it was in England. ${ }^{105}$ Given the rule's close association with the literal approach to interpretation, ${ }^{106}$ it is unsurprising that as the purposive approach became the norm in New Zealand, it was shortly

98 This change had government approval but did not require legislative amendment or a change to Standing Orders as history notes are added by the Clerk of the House after the Bill is passed and do not form part of the Act. They have the same status as the statement that says who administers the Act: Ian Jamieson, Deputy Chief Parliamentary Counsel (Drafting), to the writer "Legislative History Notes" (17 August 2006) Email.

99 Francis Bennion Statutory Interpretation - A Code (4 ed, Butterworths, London, 2002) 499 [Statutory Interpretation - A Code].

100 Ibid, 94.

101 Burrows Statute Law in New Zealand, above n 7, 187. See also Glazebrook "Filling the Gaps", above n 64, 172.

102 Zander, above n 28, 152. See also Pou v British American Tobacco (New Zealand) Ltd [2006] 1 NZLR 661, para 13 (CA) William Young J for the Court.

103 Daniel Greenberg "The Nature of Legislative Intention and Its Implications for Legislative Drafting" (2006) 27 Stat LR 15, 23.

104 Francis Bennion "Hansard - Help or Hindrance? A Draftsman's View of Pepper v Hart" (1993) 14 Stat LR $149,152$.

105 NZLC R17, above n 8, para 124.

106 Burrows "The Changing Approach to the Interpretation of Statutes", above n 42, 983. 
consigned to history after Cooke $\mathrm{J}$ (as he then was) said it would be "unduly technical to ignore such an aid". ${ }^{107}$ Although the courts have previously expressed concern about the extent to which they have been invited to rely on parliamentary materials, including Hansard, in interpreting legislation, ${ }^{108}$ the academic and judicial consensus today is that the broader contextual picture this material provides is useful as a guide to purpose, ${ }^{109}$ especially when the meaning of a provision is unclear. ${ }^{110}$ And, confirming the point made previously when contrasting literalism and purposiveness, legislative history provides an objective counterbalance to judges' personal preferences. $^{111}$

Notwithstanding the select committee's concerns about the use of legislative history to inform interpretation, it is apparent that the courts have continued to have recourse to relevant parliamentary materials since the enactment of section 5(1). It is equally apparent that they have done so in a principled way with an objective focus on Parliament's intention. Frucor is one such case. Agnew is another. However, the Supreme Court's decision in Awatere Huata v Prebble ${ }^{112}$ is perhaps the pre-eminent example of the importance of legislative history as a guide to ascertaining meaning. The Court had to decide whether Donna Awatere Huata had "acted in a way that has distorted ... the proportionality of political party representation in Parliament". ${ }^{113}$ In rejecting the "narrow"114 construction adopted by the majority in the Court of Appeal (which effectively limited the inquiry to an MP's voting behaviour), their Honours adopted a "textual"115 interpretation that had regard to the 1986 Royal Commission Report, ${ }^{116}$ the complete drafting history including changes made to "strengthen" the Bill, ${ }^{117}$ Standing Orders, Hansard, and the "centrality" of political

107 Marac Life Assurance Ltd v Commissioner of Inland Revenue [1986] 1 NZLR 694, 701 (CA) Cooke J.

108 Lands Case, above n 2. See also Wellington International Airport Ltd v Air New Zealand Ltd [1993] 1 NZLR 671 (CA).

109 McGrath "Purpose, Hansard, Rights and Language", above n 46, 230. See also Burrows "The Changing Approach to the Interpretation of Statutes", above n 42, 988; and Rt Hon Sir Kenneth Keith "Sources of Law, Especially in Statutory Interpretation, with Suggestions About Distinctiveness" in Rick Bigwood (ed) Legal Method in New Zealand: Essays and Commentaries (Butterworths, Wellington, 2001) 77, 92-93.

110 Glazebrook "Filling the Gaps", above n 64, 172.

111 Ibid, 172.

112 Awatere Huata v Prebble [2005] 1 NZLR 289 (SC).

113 Electoral Act 1993, s 55D(a).

114 Awatere Huata v Prebble, above n 112, para 63 Gault J, para 86 Keith J.

115 Ibid, para 51 Elias CJ.

116 Royal Commission on the Electoral System "Towards a Better Democracy" [1986] IX AJHR H3.

117 Awatere Huata v Prebble, above n 112, para 51 Elias CJ. 
parties to the electoral system and Parliament. ${ }^{118}$ As Keith $\mathrm{J}$ said, "the constitutional and parliamentary context strongly supports the ordinary, broad meaning of 'acted' and 'conduct' as used in s 55D". ${ }^{119}$ This judgment illustrates the importance of context to purposive interpretation. It also demonstrates that consideration of context does not involve a departure from the words of a statute. Parliament's intention, as expressed in the words of the Act, was central to the process of ascertaining meaning.

\section{B Temporal and Factual Context}

Parliament itself has directed that the courts have regard to matters of time and place when interpreting legislation. Section 6 of the 1999 Act provides: "An enactment applies to circumstances as they arise." Indeed, "circumstances as they arise" reflects the dictionary definition of context: ${ }^{120}$

context $\bullet n$ the circumstances that form the setting of an event, statement or idea, and in terms of which

it can be fully understood

It is submitted that in appropriate circumstances section 6 also allows the courts to have regard to the individual facts of a case when interpreting legislation. As the Hon Justice Gallen has noted, Parliament's intention is general whereas judges are obliged to consider a particular situation. ${ }^{121}$ His Honour considers that as well as giving effect to Parliament's intention, purposive interpretation required judges to take into account the effect of the legislation on those subject to it. Rejecting the suggestion that this "balancing exercise" amounted to judicial activism, he notes that judges had a "constitutional obligation" to those to whom the statute was being applied. ${ }^{122}$

Factual context is particularly relevant where concepts are expressed in general terms - as many criminal provisions are, for example, and where there are potentially serious consequences for individuals. By way of illustration, what constitutes "obscene language in a public place" 123 has been the subject of some interesting judicial comment. The words "f*** off/f*** the Police", when shouted in the presence of a large group of men, women and children attending an Anzac Day commemorative service, were held to be obscene. ${ }^{124}$ McCarthy $\mathrm{J}$ noted that, "in this class of prosecution language is weighed by contemporary standards and in the light of the particular

118 Ibid, 83-85 Keith J.

119 Ibid, para 85 Keith J (emphasis added).

120 Concise Oxford English Dictionary (10 rev ed, Oxford University Press, Oxford, 2002) 307.

121 Hon Justice Gallen "Comment: A Judge's View" in New Zealand Law Commission Legislation and its Interpretation (NZLC PP8, Wellington, 1988) 146, 149.

122 Ibid, 148-149.

123 Police Offences Act 1927, s 48; now Summary Offences Act 1981, s 4.

124 Police v Drummond [1973] 2 NZLR 263 (CA). 
circumstances and setting in which it was used". ${ }^{125}$ The same words were held merely to reflect the New Zealand vernacular "go away" when uttered to a Police officer in central Auckland on a Friday afternoon. ${ }^{126}$ More recently, Williams J noted: ${ }^{127}$

'Bugger' is an example of a word which has lost its original meaning. Publicly using the word 'bugger' in New Zealand might, even a comparatively few years ago, have risked prosecution for using indecent or obscene language in a public place. Now, however, it is frequently used on prime time television. It is now no more than a term of abuse, an expletive, an expression of annoyance.

'F***' must be seen in the same light ...

Effluxion of time coupled with changes in social attitudes, values and conditions may lead to changes in ordinary usage which may give specific (but still general) ${ }^{128}$ words and phrases a different meaning to that contemplated by the original legislators, ${ }^{129}$ or a statute may need to be applied in circumstances or to things not contemplated at the time of enactment. ${ }^{130}$ Section 6 enables old statutes to be applied in a modern world. ${ }^{131}$ For example, the courts have ruled that computer programs and disks are documents, ${ }^{132}$ computer-hacking is "damage to property", ${ }^{133}$ internet banking forms are "valuable securities", ${ }^{134}$ and downloading internet material at an employer's expense is theft. ${ }^{135}$ The need to interpret statutes "in light of modern conditions" was affirmed in $R v$ Walsh $^{136}$ when a facsimile copy of a false document was deemed to be a false document in its own right. As Glazebrook J noted, "In the modern digital age it is likely that the

125 Ibid, 265 McCarthy J (emphasis added).

126 Police v Spijkerbosch (1986) 2 CRNZ 82, 83 (DC) Judge Bremner.

127 Harris v Attorney-General (5 July 2006) HC AK BC200661190, paras 146-147 Williams J.

128 By this I mean words that are not used in a technical context, or as terms of art.

129 Alec Samuels "How to Construe Statutory Language Which has Changed its Meaning in Ordinary Usage: Fitzpatrick v Sterling Housing Association" (2001) 22 Stat LR 154, 154.

130 J F Burrows "The Interpretation Act 1999" in The Statute - Making and Meaning, above n 46, $211,217$.

131 McGrath "Purpose, Hansard, Rights and Language", above n 46, 228.

$132 R$ v Misic [2001] 3 NZLR 1 (CA).

$133 R v$ Garrett [2001] DCR 555.

$134 R v$ Simon (14 October 2004) CA 230/04

135 Elizabeth Binning "Internet Theft Conviction Unlikely to Open Floodgates" (23 August 2006) The New Zealand Herald Auckland A5.

$136 R v$ Walsh (26 June 2006) CA208/05. 
very act of forgery may involve some kind of imaging ... Forgers these days do not work with quill and parchment." 137

However, temporal and factual context justifies "updating" statutory language only to the extent the words themselves and the statute's purpose allow. ${ }^{138}$ In the examples cited, the words and purpose of the Crimes Act ${ }^{139}$ admitted a purposive construction that included new ways of committing old crimes; the courts were not "legislating" for new crimes.

\section{Precedent}

The doctrine of stare decisis is a further constraint on statutory interpretation. Although temporal and factual context may justify "updating" legislation, higher court decisions bind lower courts. ${ }^{140}$ The Court of Appeal is, even when sitting with a full bench of five judges, reluctant to overturn its own decisions, "merely on the ground [of] a finely balanced point of statutory interpretation". ${ }^{141}$

Until the Supreme Court was established as New Zealand's final court of appeal, ${ }^{142}$ the Court of Appeal was, in practice, the final court of appeal in most cases. As Blanchard $\mathrm{J}$ noted in $R v$ Hines, "[t]he appropriate policy on precedent for a (de facto) final appellate Court should mix caution and flexibility." ${ }^{143}$ Richardson J went on to say: ${ }^{144}$

This Court must not gain a reputation for easily being persuaded to depart from its earlier decisions ... On the other hand, when sitting as a Full Court it must have the freedom of action to be able to restate the [common] law of New Zealand as changes in social conditions and legal developments in this country and elsewhere require.

Changes in social conditions and legal developments may also inform questions of statutory interpretation. The need for certainty in the law demands judges proceed with caution, ${ }^{145}$ but precedent is a not an insurmountable barrier. In Dahya $v$ Dahya ${ }^{146}$ a full bench of the Court of

137 Ibid, para 39.

138 Glazebrook "Filling the Gaps", above n 64, 166.

139 Crimes Act 1961, ss 229A, 246, 263, 264, 298.

140 Burrows Statute Law in New Zealand, above n 7, 120.

141 Dahya v Dahya [1991] 2 NZLR 150, 155-6 (CA) Cooke P.

142 Supreme Court Act 2003.

$143 R v$ Hines [1997] 3 NZLR 529, 587 (CA) Blanchard J.

144 Ibid (emphasis added).

$145 R v$ Chilton [2006] 2 NZLR 241, para 83 (CA) Glazebrook J for the Court.

146 Dahya v Dahya, above n 141, 155-156 Cooke P. 
Appeal ${ }^{147}$ overturned its majority decision in Brown v Brown, ${ }^{148}$ preferring Cooke J's dissent. The interpretation question involved sections in the Matrimonial Property Act 1976 concerning equal sharing of the husband's interest in the matrimonial home. The court unanimously found that "it is entirely appropriate ... to review an earlier decision under this important social legislation." ${ }^{149}$ In Brown, the wife had received nothing after nine years of marriage. Bisson J considered departure from this precedent was warranted "in the interests of justice, to right an anomaly and give effect to one of the most fundamental principles of the Act". 150

Similarly, Aoraki Corporation Ltd v McGavin ${ }^{151}$ saw a unanimous reversal of the Court's controversial decision in Brighouse Ltd $v$ Bilderbeck, ${ }^{152}$ delivered only four years previously. Brighouse was, arguably, in the sense used in this paper, "judicially activist". ${ }^{153}$ The majority ${ }^{154}$ upheld the Employment Court decision awarding redundancy compensation under section 40(1)(c)(i) and (ii) of the Employment Contracts Act 1991 - despite acknowledging the redundancies were genuine. ${ }^{155}$ Although it is difficult to identify a cogent ratio across the three majority judgments, ${ }^{156}$ the thrust of the reasoning appears to be that the Court could take matters "of equity and good conscience" 157 into account in interpreting the Act's provisions on unjustified dismissal. In Aoraki the Court concluded that the Employment Court could not use its "equity and good conscience" jurisdiction ${ }^{158}$ to "frustrate the policy of legislation" by departing from "the proper interpretation of ... s 27(1)(a)". ${ }^{159}$ In a separate judgment Thomas J said: "To decline to

147 Cooke P, Casey, Bisson and Hardie Boys JJ; Richardson J dissenting

148 Brown v Brown [1984] 1 NZLR 374 (CA).

149 Dahya v Dahya, above n 146, 161 Richardson J. See also 157 Cooke P; 163 Casey J; 166 Bisson J; and 168 Hardie Boys J.

150 Ibid, 166 Bisson J.

151 Aoraki Corporation Ltd v McGavin [1998] 3 NZLR 276 (CA) Richardson P, Gault, Henry, Keith, Blanchard, Tipping and Thomas JJ.

152 Brighouse Ltd v Bilderbeck [1995] 1 NZLR 158 (CA).

153 For a trenchant criticism of Brighouse see Kerr, above n 20.

154 Cooke P, Casey and Bisson JJ; Richardson and Gault JJ dissenting.

155 Brighouse Ltd v Bilderbeck, above n 152, 161 Cooke P.

156 See Aoraki Corporation Ltd v McGavin, above n 151, 292 Richardson P, Gault, Henry, Keith, Blanchard and Tipping JJ.

157 Brighouse Ltd v Bilderbeck, above n 152, 166 (CA) Cooke P.

158 Employment Contracts Act 1991, s 104(3).

159 Aoraki Corporation Ltd v McGavin, above n 151, 298 Richardson P, Gault, Henry, Keith, Blanchard and Tipping JJ. 
review [Brighouse] would be to deny the law its social utility and capacity to develop."160 Thomas $\mathrm{J}$ saw the development of the law in this case as reflecting a return to Parliament's "manifest" intention. ${ }^{161}$

The absence of any justification for "developing" the law saw the Court of Appeal in Jones $v$ Sky City Auckland Ltd ${ }^{162}$ decline to revisit its decision on section 67 of the Casino Control Act 1990 delivered less than 12 months previously. ${ }^{163}$ Keith $\mathrm{J}$ noted no "social policy or any other viewpoint" had been advanced in support of such a review. ${ }^{164}$ However, the Court did revisit its interpretation of section 67, starting with "the plain words of s 67 read in their statutory and wider context and with reference to their purpose". ${ }^{165}$ The "wider context" included "English statutes from the time of Henry VIII", ${ }^{166}$ official reports and scholarly works, and the Queensland statute on which the Act was based. ${ }^{167}$

Jones was cited in $R v$ Chilton, ${ }^{168}$ in which the appellants challenged their convictions for benefit fraud. As the Court noted: ${ }^{169}$

It can ... be inferred from Keith J's comments that the Court may be more inclined (although still taking a cautious approach) to revisit decisions involving fundamental human rights or changes in economic and social conditions. Adapting the law to take into account changed conditions is consistent with the court's role in the development of the common law and with the principle of statutory interpretation which gives statutes a "dynamic" or "ambulatory" interpretation and treats them as applying to circumstances as they arise - see s 6 of the Interpretation Act ...

The Court in Chilton declined to review its decision in Nicholson v Department of Social Welfare, ${ }^{170}$ noting that: ${ }^{171}$

160 Ibid, 301Thomas J.

161 Ibid, 303 Thomas J.

162 Jones $v$ Sky City Auckland Ltd [2004] 1 NZLR 192 (CA).

163 Sky City Auckland Ltd v Wu [2002] 3 NZLR 621 (CA).

164 Jones v Sky City Auckland Ltd, above n 162, para 15 Keith J for the Court.

165 Ibid, para 17 Keith J for the Court.

166 Ibid.

167 Ibid, paras 18-21 Keith J for the Court.

$168 R v$ Chilton, above $\mathrm{n} 145$.

169 Ibid, para 89 Glazebrook $\mathrm{J}$ for the Court (emphasis added).

170 Nicholson v Department of Social Welfare [1999] 3 NZLR 50 (CA).

$171 R v$ Chilton, above n 145, para 107 Glazebrook J for the Court. 
The case related to a fine point of statutory interpretation. We were pointed to no criticism, academic or otherwise, of the majority's decision, there have been no relevant developments in other jurisdictions and there is no suggestion of social or economic change necessitating a revised approach.

The clear inference to be drawn from this statement is that if the context ("social or economic change") had dictated otherwise, the Court may have been persuaded to review its interpretation of the relevant statutory provision. One of the reasons the Court gave for declining to do so was that "applying a new rule to [the appellants] would have breached ... s 26(1) of BORA". ${ }^{172}$ The nexus between BORA, statutory interpretation and context is the focus of the following section.

\section{New Zealand Bill of Rights Act 1990}

Sections 5 and 6 of BORA are the principal interpretation provisions where human rights are engaged, ${ }^{173}$ although section 4 precludes the invalidation of BORA-inconsistent legislation. Section 5 is expressed in general terms. It provides that rights and freedoms affirmed by BORA (also expressed in general terms) "may only be subject to such reasonable limits prescribed by law as can be demonstrably justified in a free and democratic society". Section 6 directs that a BORAconsistent interpretation of legislation "shall be preferred to any other meaning". The flexibility a generally-worded BORA offers facilitates "easy adaptation to particular circumstances or changes in society", ${ }^{174}$ but, at the same time, reinforces the importance of temporal and factual context in ensuring BORA-oriented interpretation is both as informed and as objective as possible.

The relevance of context becomes clear when one considers that a BORA-consistent interpretation may alter retrospectively the interpretation of a statute enacted before BORA and previously interpreted in a particular way. ${ }^{175}$ As Gault $\mathrm{J}$ stated in $R v$ Poumako, the need for new interpretations of old statutes derives from BORA itself: ${ }^{176}$

The meaning to be preferred is that which is consistent (or more consistent) with the rights and freedoms in [BORA]. It is not a matter of what the legislature (or an individual member) might have intended.

172 Ibid, para 109 Glazebrook J for the Court.

173 Rt Hon Dame Sian Elias "Fighting Talk and Rights Talk" (Gilbert \& Tobin Centre of Public Law Constitutional Law Conference, Sydney, 18 February 2005) 5 ["Fighting Talk and Rights Talk"].

174 Hon Susan Glazebrook "The New Zealand Bill of Rights Act 1990: Its Operation and Effectiveness" (South Australian State Legal Convention, Adelaide, 22-23 July 2004) para 36 ["The New Zealand Bill of Rights Act 1990: Its Operation and Effectiveness"].

175 Flickinger v Crown Colony of Hong Kong [1991] 1 NZLR 439, 440 (CA) Cooke P for the Court. See also Quilter v Attorney-General [1998] 1 NZLR 523, 579 (CA) Tipping J; Glazebrook "The New Zealand Bill of Rights Act 1990: Its Operation and Effectiveness", ibid, para 35.

$176 R$ v Poumako [2000] 2 NZLR 695, 702 (CA) Gault J. 
The Court of Appeal was recently faced with just such a "post-BORA interpretation of a preBORA statute" argument when it was suggested that the appointment of Acting Judges in the High Court and Court of Appeal breached the concept of judicial independence inherent in section 25(a) of BORA. ${ }^{177}$ The legislative authority for the appointment of Acting Judges dates from 1981. ${ }^{178}$ The Court acknowledged the argument required consideration of "material developments" since 1981, including a reduction in judges' retirement age, changes in pension entitlements, and development in "international norms as to judicial independence". ${ }^{179}$ However, the Court declined to express a conclusion on this point. ${ }^{180}$ The case was decided on other grounds.

1 The times they are a-changin ${ }^{\prime 181}$

Melser $v$ Police ${ }^{182}$ and Police $v$ Beggs, ${ }^{183}$ decided 33 years apart but whose factual context (peaceful political protest in Parliament grounds) is very similar, provide a useful illustration of how temporal context can affect rights-oriented interpretation. In Melser, the defendants were convicted of disorderly behaviour. In determining the meaning of the word "disorderly", ${ }^{184}$ the Court looked at dictionary definitions and legislative history. While acknowledging the importance of freedom of speech, ${ }^{185}$ the Court accorded it less weight than the "serious annoyance" ${ }^{186}$ likely to be caused to "right-thinking members of the public" 187 (but principally, it would seem, the visiting United States Vice President and Members of Parliament).

Thirty-three years later, Melser was cited in Beggs not in the context of the "annoyance" caused to the Speaker who wanted protestors in Parliament grounds arrested for trespass, but as authority for the proposition that "the right to protest against political decisions is one of the most precious of our individual freedoms". ${ }^{188}$ After holding that the Speaker could have and should have acted in a

$177 R v$ Te Kahu [2006] 1 NZLR 459 (CA).

178 Judicature Act 1908, ss 11 and 11A.

$179 R v$ Te Kahu, above n 177, para 43 William Young J for the Court.

180 Ibid, paras 44-45 William Young J for the Court.

181 C) Bob Dylan 1964 - The song from the album of the same name.

182 Melser v Police [1967] NZLR 437 (SC, CA).

183 Police v Beggs [1999] 3 NZLR 615 (HC, Full Court).

184 Police Offences Act 1927, s 3D.

185 Melser v Police, above n 182, 445 McCarthy J.

186 Ibid, 445 Turner J.

187 Ibid, 439 (SC) Tompkins J.

188 Police v Beggs, above n 182, Gendall J for the Court (quoting from the unreported District Court judgment). 
way consistent with BORA, but did not, Gendall J ordered a permanent stay of proceedings. ${ }^{189}$ The Chief Justice has noted, writing extrajuidicially, that "in New Zealand few of us [regard] Melser as a high point in our law. The contemporary verdict was harsh. And today this case seems to belong to a different world." 190 It is that "different world" that the court had regard to when deciding Beggs.

\section{Rights-oriented purposive interpretation}

Rights-oriented interpretation has been applied to BORA itself. The absence of an explicit remedies provision has not impeded the development of remedies by the courts. In Ministry of Transport $v$ Noort ${ }^{191}$ the Court of Appeal, by a four-to-one majority, ${ }^{192}$ excluded evidence obtained in breach of section 23(1)(b). Cooke P considered the Court was obliged to "give [the right to consult a lawyer] practical effect irrespective of the state of our law before [BORA]. What is practical effect can only be a question of fact dependent on the particular circumstances." 193 Richardson J noted: "[BORA] ss 4 and 6 should ... be given the purposive effect mandated ... by s 5(j) of the [1924 Act]." 194 The contextual analysis that followed included contemporary international human rights statements, the balance to be struck between individual and community interests, and the scheme of the breath/blood-alcohol legislation. ${ }^{195}$

In Martin v Tauranga District Court, ${ }^{196}$ a 17 -month delay in bringing a case to trial was deemed "undue delay" under BORA section 25(b). The delay resulted from an unjustified action by the prosecutor, and this context was important in deciding the remedy (a stay of proceedings) because, as Richardson $\mathrm{J}$ noted, each such case has to be considered individually: "The [remedy] should be directed to the values underlying the particular right. The remedy ... should be proportional to the particular breach and should have regard to other aspects of the public interest." 197 Arguably, if the factual context had not included prosecutorial misconduct the outcome may have been different.

\footnotetext{
189 Ibid, 632 Gendall $\mathrm{J}$ for the Court.

190 Elias "Fighting Talk and Rights Talk", above n 173, 2 (emphasis added).

191 Ministry of Transport $v$ Noort [1992] 3 NZLR 260 (CA).

192 Cooke P, Richardson, Hardie Boys and McKay JJ; Gault J dissenting.

193 Ministry of Transport v Noort, above n 191, 270 Cooke P (emphasis added).

194 Ibid, 278 Richardson J (McKay J concurring). See also 286 Hardie Boys J.

195 Ibid, 279-281 Richardson J (McKay J concurring).

196 Martin v Tauranga District Court [1995] 2 NZLR 419 (CA).

197 Ibid, 428 (CA) Richardson J.
} 
Baigent's Case ${ }^{198}$ is perhaps the most controversial of the early "remedies" cases; it generated vociferous accusations of judicial activism. ${ }^{199}$ Briefly, the case involved a search warrant issued on the basis of mistaken information. The police continued with the search after becoming aware of the mistake. The civil proceedings that followed included a damages claim for breach of section 21 of BORA. The claim was struck out by the High Court and the plaintiff appealed. In creating a new remedy of public law compensation, the majority in the Court of Appeal ${ }^{200}$ undertook a balancing exercise in statutory interpretation.

The (seemingly) insurmountable hurdles of Crown immunity ${ }^{201}$ and police immunity ${ }^{202}$ were overcome by the majority's finding that these tort-based immunities did not apply to a BORA-based public law claim. ${ }^{203}$ International jurisprudence and BORA's legislative history formed a major part of the majority analysis. In rejecting the Crown argument based on the exclusion of the remedies clause from the Bill, Cooke P referred to the Bill's explanatory note, which said: "Action that violates those rights and freedoms will be unlawful. The Courts might enforce those rights in different ways in different contexts." 204 In an interesting (if somewhat circular) argument Cooke P noted: 205

[BORA] is binding on [the courts], and we would fail in our duty if we did not give an effective remedy to a person whose legislatively affirmed rights have been infringed. In a case such as the present the only effective remedy is compensation. A mere declaration would be toothless.

Gault $\mathrm{J}$, although dissenting on the question of public law compensation, noted that in interpreting BORA it was appropriate to have "greater regard to the object and purpose to be discerned from the statute itself in its wider setting ... [and] its international context" ${ }^{206}$

The government asked the Law Commission to investigate whether legislation reversing Baigent's Case was required. The Commission said it was not ${ }^{207}$ and the government concurred. In

198 Baigent's Case, above n 26.

199 Campbell "Judicial Activism - Justice or Treason?", above n 21, 307, 320. See also J A Smillie "'Fundamental' Rights, Parliamentary Sovereignty and the New Zealand Court of Appeal" (1995) 111 LQR $209,216$.

200 Cooke P, Casey, Hardie Boys and McKay JJ; Gault J dissenting.

201 Crown Proceedings Act 1950, s 6(5).

202 Crimes Act 1961, ss 26-27; Police Act 1958, s 39.

203 Baigent's Case, above n 26, 677 Cooke P.

204 Ibid, 677 Cooke P (emphasis added).

205 Ibid, 676 Cooke P.

206 Ibid, 707 Gault J (emphasis added). 
the writer's view the principled way in which judges have approached public law compensation cases post-Baigent's Case does not support criticisms that they have been judicially activist. That label would have been appropriate if different (lesser) standards had been applied to deny "undeserving" plaintiffs compensation for breach of BORA rights. ${ }^{208}$

\section{E Treaty of Waitangi}

The Treaty of Waitangi (the Treaty) is not part of domestic law in New Zealand and its terms cannot be enforced directly in the courts. ${ }^{209}$ However, since the State-Owned Enterprises Act 1986 (SOE Act) was passed, references to the principles of the Treaty in legislation have become increasingly common. ${ }^{210}$ Such references do not give the Treaty the force of law, but they facilitate its use as an aid to interpretation. ${ }^{211}$

Section 9 of the SOE Act provides: "Nothing in this Act shall permit the Crown to act in a manner that is inconsistent with the principles of the Treaty of Waitangi." Section 9 was a response to an interim Waitangi Tribunal report addressing claimants' concerns about the availability of Crown land to settle Treaty claims. ${ }^{212}$ Parliament did not define "the principles;" this was "deliberately"213 left to the courts and, as a previous Minister of Treaty Negotiations notes, "in what has been seen by some as unusual and undesirable judicial activism ... the judiciary rapidly responded". 214

The Lands Case $^{215}$ was the section 9 "test case". Cooke P considered that a "broad, unquibbling and practical interpretation [was] demanded". ${ }^{216}$ He agreed with the applicant that the

207 New Zealand Law Commission Crown Liability and Judicial Immunity - A Response to Baigent's case and Harvey v Derrick (NZLC R37, Wellington, 1997) para 108.

208 Attorney-General v Taunoa [2006] 2 NZLR 457 (CA). But see Kerr v Attorney-General [1996] DCR 951.

209 Hoani Te Heu Heu Tukino v Aotea District Māori Land Board [1941] AC 308 (PC); Lands Case, above n 2; New Zealand Māori Council v Attorney-General [1994] 1 NZLR 513 (CA) [Broadcasting Assets No 1]; New Zealand Māori Council v Attorney-General [1996] 3 NZLR 140 (CA) [Radio Assets No 2].

210 Crown Research Institutes Act 1992, s 10. See also Energy Efficiency and Conservation Act 2000, s 6(d); Hazardous Substances and New Organisms Act 1996, s 8; Historic Places Trust Act 1993, s 115(2); Land Transport Management Act 2003, s 4; Local Government Act 2002, s 4; Resource Management Act 1991, s 8 .

211 Rt Hon Sir Douglas Graham "The Legal Reality of Customary Rights for Māori" (Occasional Paper No 6, Stout Research Centre, Victoria University of Wellington, Wellington, 2001) 22.

212 Waitangi Tribunal Interim Report to the Minister of Māori Affairs on State-Owned Enterprises Bill: Wai 1177 (Waitangi Tribunal, Wellington, 8 December 1996).

213 Lands Case, above n 2, 659 Cooke P.

214 Graham, above n 211, 22.

215 Lands Case, above n 2. 
Treaty should be "interpreted widely and effectively and as a living instrument taking account of the subsequent developments of international human rights norms". ${ }^{217}$ Cooke P proceeded to look at a wide range of extrinsic material including Hansard, historical material, other legislation with "principles" references, Waitangi Tribunal Reports (which he thought should be given "much weight"), and the 1980 Report of the Royal Commission of Inquiry concerning the Māori Land Courts. ${ }^{218}$ Cooke P thought the "spirit" of the Treaty was a more important guide to meaning than the (different) English and Māori texts. ${ }^{219}$

The end result of this analysis was a conclusion that the "principles of the Treaty" included partnership, the signatories' duty to act with utmost good faith, responsibilities analogous to fiduciary duties and, importantly, active protection. ${ }^{220}$ The other judges (Richardson, Somers, Casey and Bisson JJ) undertook similar contextual analyses. The Court concluded unanimously that the Crown should be restrained from transferring or disposing of land to newly established stateowned enterprises until safeguards guarding against prejudice to Treaty claims and which had the approval of the applicant had been established. ${ }^{221}$

While the government may have been unhappy with the outcome of this case (because of the restrictions it placed on the major state-sector reforms underway at the time), in the writer's opinion, the process followed by the Court was entirely appropriate. The five judges did not fail to apply available "relevant, existing, clear, positive law" nor did their judgments reflect their own "moral, political or religious views at to what the content of the [principles of the Treaty] should be". It is, therefore, unfair to characterise either the outcome or the process of ascertaining meaning as judicially activist. When an Act is silent on the crucial issue of interpretation (as the SOE Act was), it is entirely appropriate (and it is submitted essential) for judges to have regard to external contextual material in ascertaining meaning. Subsequent cases involving Treaty principles have followed the lead established in the Lands Case. ${ }^{222}$

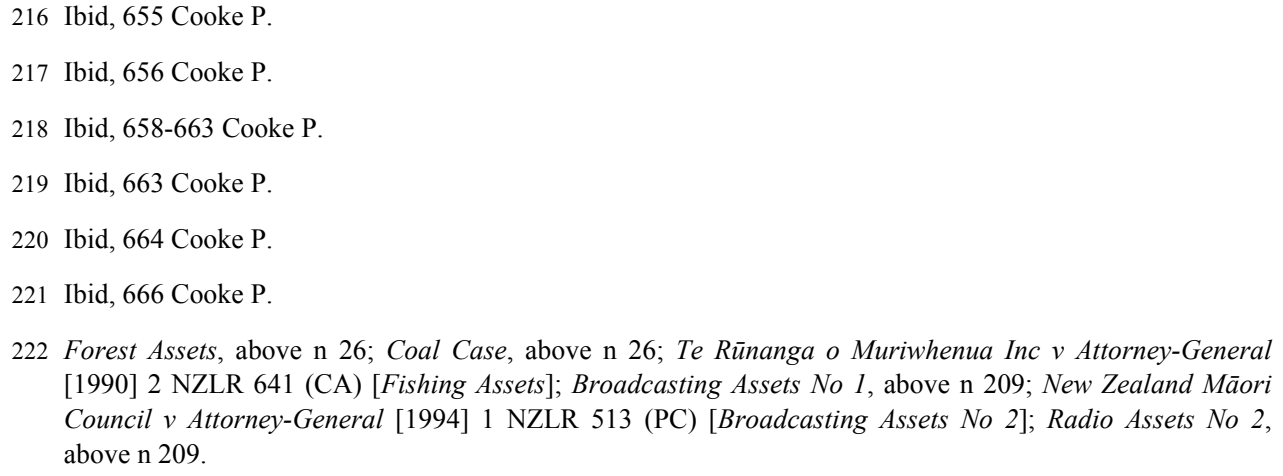
[1990] 2 NZLR 641 (CA) [Fishing Assets]; Broadcasting Assets No 1, above n 209; New Zealand Māori Council v Attorney-General [1994] 1 NZLR 513 (PC) [Broadcasting Assets No 2]; Radio Assets No 2, above $\mathrm{n} 209$. 
Carter Holt Harvey $L t d^{223}$ provides a useful summary of principles derived from Waitangi Tribunal decisions and court judgments over the last 20 years. It illustrates that like other interpretation aids, Treaty principles are not fixed in time - or context. In Bleakley, ${ }^{224}$ a full Bench of the High Court declined the respondent's request to define how "spiritual values ... can be measured, quantified, weighed and balanced" in accordance with the requirements of the Hazardous Substances and New Organisms Act 1996. Goddard J noted: 225

Active protection [may require] decisions to be made according to the tenets of Māori spiritual belief, ...

but whether [those beliefs] are significant in a particular case will depend on all the circumstances and

issues arising.

Similarly, McGechan J noted active protection was not a "determinant" consideration and it was open for the Authority to find, as it did, that the adverse effects on Māori did not outweigh other factors, but that "[d]ifferent outcomes remain open, according to their facts."226

In Takamore, ${ }^{227}$ Ronald Young $\mathrm{J}$ undertook a statutory interpretation exercise balancing sections 6, 7 and 8 of the Resource Management Act 1991. The respondent argued that "consultation" concerning a proposed roadway cutting through wāhi tapu and urupā satisfied its statutory obligation to provide for the "relationship of Māori with their culture and traditions ..."228 and to have "particular regard to kaitiatikanga". 229 The respondent further argued that because "consultation" was sufficient to satisfy these two obligations, that in turn was sufficient to satisfy its obligation to "take into account [Treaty] principles". ${ }^{230}$ Ronald Young J disagreed. He found that whether or not the decision-maker has had sufficient regard to its section 6 and section 7 obligations to satisfy section 8 "will depend very much on the facts of each case". ${ }^{231}$ The facts of this case did not establish compliance with section $8 .^{232}$

223 Carter Holt Harvey Ltd v Te Rūnanga o Tūwharetoa Ki Kawerau [2003] 2 NZLR 349, paras 27-28 (HC) Heath J.

224 Bleakley v Environmental Risk Management Authority [2001] 3 NZLR 213 (HC, Full Court).

225 Ibid, paras 363-365 McGechan and Goddard JJ.

226 Ibid, para $87 \mathrm{McGechan}$ and Goddard JJ.

227 Takamore Trustees v Kapiti Coast District Council [2003] 3 NZLR 496 (HC).

228 Resource Management Act 1991, s 6(e).

229 Resource Management Act 1991, s 7(a).

230 Resource Management Act 1991, s 8.

231 Takamore Trustees v Kapiti Coast District Council, above n 227, para 91 Ronald Young J.

232 Ibid, paras 86-87 Ronald Young J. 
While references to the principles of the Treaty facilitate the Treaty's use as an aid to statutory interpretation, the significance of the sea-change in public and judicial attitudes to the significance of the Treaty over the last 30 years $^{233}$ should not be overlooked. Where the Treaty was once described as a "simple nullity"234 it is now seen as "part of the fabric of New Zealand society". ${ }^{235}$ In the writer's view, this change in attitude would have seen increasing use of the Treaty as an aid to interpretation. It reflects the relevance of temporal and factual context discussed previously. The increasing willingness of the courts to have regard to Treaty principles, absent a direct legislative reference, ${ }^{236}$ supports this conclusion.

\section{COURT OF APPEAL AND SUPREME COURT JUDGMENTS: 2006}

In an article published in the 1999 New Zealand Universities Law Review (the Allan analysis), James Allan presented the results of an empirical analysis of the Court of Appeal's use of interpretive resources as an aid to statutory interpretation. ${ }^{237}$ The results covered all reported Court of Appeal judgments in 1976, 1986 and 1996. The writer has taken Mr Allan's methodology and applied it to reported Court of Appeal and Supreme Court judgments a decade on to see what change, if any, there has been in the use of extrinsic material as an aid to interpretation since the enactment of section 5(1) of the 1999 Act. The cases analysed appear in the New Zealand Law Reports (as do the cases in the Allan analysis) in 2006. The results are presented in Appendices A, B and C. ${ }^{238}$ The results from the 1999 survey are noted for comparative purposes.

The writer has attempted to replicate the Allan analysis methodology as far as possible, but because the article did not explain the basis by which certain "category allocation" decisions were made, a degree of subjectivity is involved. For example, the Allan analysis categories include "literal approach" and "purposive approach". For current purposes a "literal approach" classification was assigned only when it was clear that the judge was explicitly rejecting an exhortation to adopt an expansive interpretation. Conversely, a "purposive approach" classification was assigned only when it was clear that the judge was adopting a broad (or narrow) interpretation that she or he thought was necessary on the facts of the case, but where an alternative interpretation was possible.

233 Graham, above n 211, 22.

234 Wi Parata v Bishop of Wellington (1877) 3 NZ Jur (NS) 72, 77 (SC) Prendergast CJ.

235 Huakina Development Trust v Waikato Valley Authority [1987] 2 NZLR 188, 210 (HC) Chilwell J.

236 Graham, above n 211, 23.

237 Allan, above n 10.

238 Appendix A includes only "true" interpretation cases where the meaning of a statutory provision was at issue; fact-based disputes focusing on the application of a statute in a given situation are listed in Appendix C. 
The results of the 2006 survey show an increasing use of legislative history as an aid to interpretation. That trend may be attributable to the increasing reliability of such resources. Changes to Standing Orders following the implementation of the Mixed Member electoral system in 1996 mean a Bill's legislative history is more fully documented. The changes include a detailed select committee commentary on reporting back and full reporting of the Committee of the Whole debate in Hansard. ${ }^{239}$ While it is not possible to draw firm conclusions in other areas, there does appear to be an increasing use of secondary sources, including journals, texts and relevant statutory developments overseas.

Two tentative conclusions can be drawn from the evidence that other statutes are being referred to more frequently. First, when considering the purpose of a statute, the courts are conscious of the need to ensure that, where possible, the interpretation of one statute is consistent with the statute book as a whole. For example, the primary question in Johnson $v$ Felton ${ }^{240}$ was whether the twoyear period in section 47(2) of the Property (Relationships) Act 1976 defined the class of (the husband's) creditors able to challenge the relationship property agreement or whether it operated as a limitation period. In allowing the wife's appeal against Venning J's judgment setting aside the agreement, the Court of Appeal noted: ${ }^{241}$

We are bolstered in our view that the two-year period ... is a limitation period by the fact this interpretation fits more easily into the scheme of the $\mathrm{P}(\mathrm{R}) \mathrm{A}$ itself and the general insolvency regime.

Context is important in the interpretation of legislative provisions ...

That "general insolvency regime" included section 60 of the Property Law Act 1952 and sections 54-57 of the Insolvency Act 1967.

The second tentative conclusion is closely related to the first, namely that consideration of "purpose" under section 5(1) of the 1999 Act may involve something more than considering an individual Act's purpose provision in isolation. Section 5(1) itself was referred to infrequently, but that is not surprising given the long-standing acceptance of purposive interpretation as the "cardinal rule"242 of interpretation. In General Distributors Ltd v Casata Ltd McGrath J simply noted that "the meaning of the language ... is to be ascertained according to orthodox principles of purposive interpretation rather than on a restrictive basis". ${ }^{243}$ Of the 23 judgments in which a "literal" or "purposive" approach to interpretation was identified, all of which included reference to a variety of

239 J F Burrows and John Fogarty "Statutory Interpretation" (NZLS Seminar, Wellington, April 2001) 8.

240 Johnson v Felton [2006] 3 NZLR 475 (CA, SC).

241 Ibid, para 139 (CA) Glazebrook and McGrath JJ (emphasis added). The Supreme Court dismissed the creditors' appeal.

$242 R v$ Pora, above n 33, para 103 Keith, Gault and McGrath JJ.

243 General Distributors Ltd v Casata [2006] 2 NZLR 721, para 117 (SC). 
external material, ten referred directly to Parliament's intention when enacting the legislation. In two instances the Court of Appeal declined to revisit an earlier interpretation that "Parliament had not seen fit to amend". 244 Explicit recognition of the relevance of Parliament's intention to the process of ascertaining meaning is not indicative of judicial activism.

There was one example of the Supreme Court overturning the Court of Appeal on a question of interpretation - on the basis of an argument raised for the first time in oral argument before the Court, that "had not been signalled even in the written submissions required under the Supreme Court Rules 2004". 245 This was, as Blanchard J noted, "unsatisfactory ... but as the argument was one directed at the interpretation of a statute, the Court could not properly decline to consider it". ${ }^{246}$ The clear inference is that if the argument had not related to a question of statutory interpretation the Court may have declined to hear it.

\section{CONCLUSION}

The axiom that what Parliament says is what it means must be balanced with the fact that Parliament does not make laws in a vacuum. "Context" may seem an abstract or uncertain concept if considered in isolation, but as this paper demonstrates, it crystallises the moment an enactment is applied to a particular situation at a particular time. Decided cases have been used to show why and when courts have regard to extrinsic material when interpreting legislation. Such material includes legislative history, temporal and factual context, precedent, BORA, and the principles of the Treaty. Numerous other external contextual considerations, such as international treaties, customary international law, other human rights legislation, privacy principles, and legislative and judicial developments in similar overseas jurisdictions may also inform interpretation. Any of these could be substituted for the key contextual elements discussed in this paper and, it is submitted, a similar conclusion about the relevance of context would result.

Context is the essential link joining the bare words of a statute with the intention of Parliament and the expectations and understanding of those subject to the law. It enhances the rule of law. As the Legislation Advisory Committee Guidelines note: "Context is vital". ${ }^{247}$ And as the 1999 Act itself states: "This Act applies to an enactment that is part of the law of New Zealand ... unless [t]he context of the enactment requires a different interpretation. ${ }^{248}$ Context, it seems, is always vital to

$244 R v$ Chilton, above n 145, para 108; see also Pou v British American Tobacco (New Zealand) Ltd, above $\mathrm{n}$ 102 , para 38 .

245 Commerce Commission v Telecom Mobile Ltd [2006] 3 NZLR 323, para 15 (SC) Blanchard J for the Court.

246 Ibid, para 15 Blanchard J for the Court.

247 Legislation Advisory Committee, above n 96, para 3A.1.12.

248 Interpretation Act 1999, s 4(1)(b) (emphasis added). 
the process of ascertaining meaning. The analysis of reported Court of Appeal and Supreme Court cases in 2006 confirms this.

The writer has suggested that concern about "judicial activism" was behind Parliament's decision to omit the reference to context when enacting section 5(1). This paper demonstrates that this concern about the outcome of certain high profile cases (but not others, as Lesa and Frucor demonstrate) obscures the rationale behind the process that the courts follow when interpreting legislation. That process reflects Parliament's long-standing directive that the courts adopt a purposive approach to interpreting legislation. If consideration of context is omitted from the process of interpreting statutes, judges would be little more than Humpty Dumpty, asserting that "[w]hen $I$ [interpret] a word ... it means just what I choose it to mean - neither more nor less."249 That would be judicially activist - but that is not what the courts do.

Having introduced this paper with a quote from the late Lord Cooke's judgment in the Lands Case, it is appropriate to end with another quote from that case: "If the judiciary has been able to play a role to some extent creative, that is because the legislature has given the opportunity." 250

249 Lewis Carroll Through the Looking-Glass - and What Alice Found There (trans Roger Lancelyn Green, Oxford University Press, London, 1971) 190 (emphasis in original).

250 Lands Case, above n 2, 668 Cooke P. 
APPENDIX B - PERCENT OF TOTAL CASES INVOLVING STATUTORY INTERPRETATION

\begin{tabular}{|l|c|c|c|c|}
\cline { 2 - 5 } \multicolumn{1}{c|}{} & Year 1976* & Year 1986* & Year 1996* & Year 2006 \\
\hline Total Cases & 59 & 72 & 86 & 68 \\
\hline Statutory Interpretation & 35 & 40 & 55 & 28 \\
\hline Percent & 59.32 & 55.36 & 63.95 & 41.18 \\
\hline
\end{tabular}

* Source: James Allan "Statutory Interpretation and the Courts" (1999) 18 NZULR 439, 454. 
APPENDIX C - CASES NOT INVOLVING STATUTORY INTERPRETATION

\begin{tabular}{|c|c|c|}
\hline $\begin{array}{l}\text { Link Technology } 2000 \text { Ltd v } \\
\text { Attorney-General }\end{array}$ & [2006] 1 NZLR 1 (CA) & Practice and procedure - Costs \\
\hline $\begin{array}{l}\text { Gulf Corporation Ltd v Gulf } \\
\text { Harbour Investments Ltd }\end{array}$ & [2006] 1 NZLR 21 (CA) & $\begin{array}{l}\text { Property law - Vendor and } \\
\text { purchaser - Option to purchase } \\
\text { land }\end{array}$ \\
\hline Mellon v Attorney-General & [2006] 1 NZLR 345 (CA) & $\begin{array}{l}\text { Criminal practice and procedure - } \\
\text { Stay of proceedings }\end{array}$ \\
\hline Bahramitash v Kumar & [2006] 1 NZLR 577 (SC) & Property law - Sale and purchase \\
\hline $\begin{array}{l}\text { A Firm of Solicitors } v \text { District } \\
\text { Court at Auckland }\end{array}$ & [2006] 1 NZLR 586 (CA) & $\begin{array}{l}\text { Criminal practice and procedure - } \\
\text { Search warrants }\end{array}$ \\
\hline Laverty $v$ Para Franchising Ltd & [2006] 1 NZLR 650 (CA) & Practice and procedure - Costs \\
\hline$R v$ Allison & [2006] 1 NZLR 721 (CA) & $\begin{array}{l}\text { Criminal law - Offences - Money } \\
\text { laundering }\end{array}$ \\
\hline$R v$ Sungsuwan & [2006] 1 NZLR 730 (SC) & $\begin{array}{l}\text { Criminal practice and procedure - } \\
\text { Appeal - Conduct of defence } \\
\text { counsel }\end{array}$ \\
\hline Verissimo v Walker & [2006] 1 NZLR 760 (CA) & Contract - Formation \\
\hline $\begin{array}{l}\text { Thai Holdings Ltd } v \text { The } \\
\text { Mountaineer Ltd }\end{array}$ & [2006] 1 NZLR 772 (CA) & $\begin{array}{l}\text { Property law - Renewal of sub- } \\
\text { lease }\end{array}$ \\
\hline Banicevich v Gunson & [2006] 2 NZLR 11 (CA) & $\begin{array}{l}\text { Trusts and trustees:- Application } \\
\text { for directions - Jurisdiction }\end{array}$ \\
\hline $\begin{array}{l}\text { Gibbons Holdings Ltd v } \\
\text { Wholesale Distributors Ltd }\end{array}$ & [2006] 2 NZLR 27 (CA) & Property law - Lease \\
\hline
\end{tabular}




\begin{tabular}{|c|c|c|}
\hline $\begin{array}{l}\text { No } 68 \text { Ltd v Eastern Services } \\
\text { Ltd }\end{array}$ & [2006] 2 NZLR 43 (CA) & $\begin{array}{l}\text { Equity - Laches - Claim for } \\
\text { specific performance }\end{array}$ \\
\hline $\begin{array}{l}\text { Manuel v Superintendent, } \\
\text { Hawkes Bay Regional Prison }\end{array}$ & [2006] 2 NZLR 63 (CA) & $\begin{array}{l}\text { Practice and procedure - Costs - } \\
\text { Habeas Corpus }\end{array}$ \\
\hline$R v$ Fatu & [2006] 2 NZLR 72 (CA) & Criminal law - Sentence \\
\hline$R v$ Rogers & [2006] 2 NZLR 156 (CA) & $\begin{array}{l}\text { Criminal practice and procedure - } \\
\text { Access to lawyer - BORA }\end{array}$ \\
\hline $\begin{array}{l}\text { Landco Albany Ltd v Fu Hao } \\
\text { Construction Ltd }\end{array}$ & [2006] 2 NZLR 174 (CA) & $\begin{array}{l}\text { Contract - Conditions - Sale and } \\
\text { purchase of land }\end{array}$ \\
\hline $\begin{array}{l}\text { Reeves v OneWorld Challenge } \\
\text { LLC }\end{array}$ & [2006] 2 NZLR 184 (CA) & $\begin{array}{l}\text { Conflict of laws - Foreign } \\
\text { judgment }\end{array}$ \\
\hline Trans Otway Ltd v Shepherd & [2006] 2 NZLR 289 (SC) & $\begin{array}{l}\text { Company law - Voidable } \\
\text { preferences }\end{array}$ \\
\hline $\begin{array}{l}\text { Jansen } v \text { Whangamata Homes } \\
\text { Ltd }\end{array}$ & [2006] 2 NZLR 300 (CA) & $\begin{array}{l}\text { Contract }- \text { Remedies - } \\
\text { Contractual right to terminate by } \\
\text { notice }\end{array}$ \\
\hline Waitakere City Council v Ioane & [2006] 2 NZLR 310 (CA) & $\begin{array}{l}\text { Employment law - Personal } \\
\text { grievance - Unjustifiable } \\
\text { dismissal }\end{array}$ \\
\hline $\begin{array}{l}\text { Television New Zealand Ltd v } \\
\text { Haines }\end{array}$ & [2006] 2 NZLR 433 (CA) & $\begin{array}{l}\text { Defamation - Pleading, practice } \\
\text { and evidence }\end{array}$ \\
\hline Attorney-General v Taunoa & [2006] 2 NZLR 457 (CA) & $\begin{array}{l}\text { Constitutional law - BORA public } \\
\text { law compensation }\end{array}$ \\
\hline$R v$ Thompson & [2006] 2 NZLR 577 (CA) & $\begin{array}{l}\text { Criminal practice and procedure - } \\
\text { Juries }\end{array}$ \\
\hline$R v$ Cumming & [2006] 2 NZLR 597 (CA) & $\begin{array}{l}\text { Criminal law - Trial - Self- } \\
\text { representation }\end{array}$ \\
\hline Rick Dees Ltd v Larsen & [2006] 2 NZLR 765 (CA) & $\begin{array}{l}\text { Property law - Vendor and } \\
\text { purchaser }\end{array}$ \\
\hline
\end{tabular}




\begin{tabular}{|c|c|c|}
\hline $\begin{array}{l}\text { Mafart } v \text { Television New } \\
\text { Zealand Ltd }\end{array}$ & [2006] 3 NZLR 18 (SC) & $\begin{array}{l}\text { Practice and procedure - Access } \\
\text { to court file - Civil or criminal } \\
\text { proceedings }\end{array}$ \\
\hline$R v$ Lee & [2006] 3 NZLR 42 (CA) & $\begin{array}{l}\text { Criminal practice and procedure - } \\
\text { Appeal time limit }\end{array}$ \\
\hline$R v E d w a r d s$ & [2006] 3 NZLR 180 (CA) & Criminal law - Sentencing appeal \\
\hline $\begin{array}{l}\text { Paper Reclaim Ltd v Aotearoa } \\
\text { International Ltd }\end{array}$ & [2006] 3 NZLR 188 (CA) & $\begin{array}{l}\text { Contract - Cancellation - } \\
\text { Damages }\end{array}$ \\
\hline Mason v Lewis & [2006] 3 NZLR 225 (CA) & $\begin{array}{l}\text { Company law - Directors - } \\
\text { Liability for reckless trading }\end{array}$ \\
\hline Caie v Attorney-General & [2006] 3 NZLR 289 (SC) & $\begin{array}{l}\text { Practice and procedure - Appeal } \\
\text { by successful party }\end{array}$ \\
\hline$R \vee L$ & $\begin{array}{l}\text { [2006] } 3 \text { NZLR } 291 \text { (CA, } \\
\text { SC) }\end{array}$ & $\begin{array}{l}\text { Criminal law - Attempts - Mens } \\
\text { rea }\end{array}$ \\
\hline $\begin{array}{l}\text { Eastern Services Ltd v No } 68 \\
\text { Ltd }\end{array}$ & [2006] 3 NZLR 335 (SC) & Equity - Laches \\
\hline $\begin{array}{l}\text { Shirley } v \text { Wairarapa District } \\
\text { Health Board }\end{array}$ & [2006] 3 NZLR 523 (SC) & Practice and procedure - Costs \\
\hline $\begin{array}{l}\text { Mafart } v \text { Television New } \\
\text { Zealand Ltd }\end{array}$ & $\begin{array}{l}\text { [2006] } 3 \text { NZLR } 534 \text { (CA, } \\
\text { SC) }\end{array}$ & $\begin{array}{l}\text { Criminal practice and procedure - } \\
\text { Access to court file (videotape of } \\
\text { plea) }\end{array}$ \\
\hline $\begin{array}{l}\text { Complaints Assessment } \\
\text { Committee v Medical } \\
\text { Practitioners Disciplinary } \\
\text { Tribunal }\end{array}$ & [2006] 3 NZLR 577 & $\begin{array}{l}\text { Evidence - Privilege - Medical } \\
\text { records }\end{array}$ \\
\hline $\begin{array}{l}\text { Lucas } v \text { Peterson Portable } \\
\text { Sawing Systems Ltd }\end{array}$ & [2006] 3 NZLR 721 (SC) & Patents - Infringement - Validity \\
\hline
\end{tabular}




\begin{tabular}{|l|l|l|}
\hline$R v$ Greer & {$[2006] 3$ NZLR 740 (SC) } & $\begin{array}{l}\text { Criminal practice and procedure - } \\
\text { Bail appeal }\end{array}$ \\
\hline$R v$ Wood & [2006] 3 NZLR 743 (CA) & $\begin{array}{l}\text { Criminal practice and procedure - } \\
\text { Evidence - Witness cross- } \\
\text { examination }\end{array}$ \\
\hline
\end{tabular}

PROCEDURAL NOTES NOT INCLUDED IN THE APPENDIX B ANALYSIS

\begin{tabular}{|c|c|c|}
\hline $\begin{array}{l}\text { NOTE Calan Healthcare } \\
\text { Properties Ltd v Ord }\end{array}$ & [2006] 1 NZLR 174 (SC) & $\begin{array}{l}\text { Company law - Constitution - } \\
\text { Interpretation of provisions }\end{array}$ \\
\hline $\begin{array}{l}\text { NOTE Brown } v \text { Attorney- } \\
\text { General }\end{array}$ & [2006] 1 NZLR 176 (SC) & $\begin{array}{l}\text { Constitutional law - BORA - } \\
\text { Fair trial - Legal aid }\end{array}$ \\
\hline $\begin{array}{l}\text { NOTE Udompum } v \text { Minister of } \\
\text { Immigration }\end{array}$ & [2006] 1 NZLR 343 (SC) & $\begin{array}{l}\text { Immigration - Natural justice - } \\
\text { Right to consult a lawyer }\end{array}$ \\
\hline NOTE Primosso Holdings Ltd & [2006] 2 NZLR 455 (CA) & $\begin{array}{l}\text { Negligence }- \text { Proceeding struck } \\
\text { out - Application for review }\end{array}$ \\
\hline NOTE Rv Edwards & [2006] 3 NZLR 349 (SC) & $\begin{array}{l}\text { Criminal practice and procedure - } \\
\text { Appeal - sentence }\end{array}$ \\
\hline NOTE Kidd v van Heeren & $\begin{array}{l}\text { [2006] } 3 \text { NZLR } 520 \text { (CA, } \\
\text { SC) }\end{array}$ & $\begin{array}{l}\text { Practice and procedure - } \\
\text { Jurisdiction - Stay of proceedings }\end{array}$ \\
\hline $\begin{array}{l}\text { NOTE Junior Farms Ltd } v \\
\text { Hampton Securities Ltd (in liq) }\end{array}$ & [2006] 3 NZLR 522 (SC) & $\begin{array}{l}\text { Practice and procedure - Appeal } \\
\text { - Miscarriage of justice }\end{array}$ \\
\hline
\end{tabular}


